\title{
Pola Dasar Penggunaan Brand Dari masa ke Masa
}

\author{
Angga Hendrawan
}

Staff Pengajar Program Studi Desain Komunikasi Visual, Fakultas Seni, Institut Informatika Indonesia (IKADO) Surabaya

Email : angga@iii.ac.id

Abstract - The problem in this study is the number of practitioners who consider branding as a job in the visual field. The purpose of this study was to identify the structure and function of the brand from time to time, so it can look a basic pattern that always exists in every development. This study uses literature by studying scientific sources. Developments brandditemukan usage patterns starting in 2250SM to the current pattern of development in the conventional use of a brand starts to become a strategic device, which is able to influence the development activities bisnis.Seiring with the times, the brand experienced a transformation function that directs a business to remain competitive to cope with change times.

Keyword :Brand, Branding, Merek.

\section{PENDAHULUAN}

Brand atau merek merupakan perangkat yang menjadi bagian dari strategi pemasaran.Perangkat ini terbentuk bersamaan dengan didirikannya sebuah kegiatan usaha, walaupun ada juga pemilik yang tidak menyadari tentang keberadaan brand pada usaha yang dijalankannya.
Disadari atau tidak, brand terbentuk dan memberikan dampak dalam kegiatan pemasaran barang atau jasa.Brand yang dikelola dengan baik memberikan fungsi yang maksimal dalam kegiatan pemasaran, sedangkan brand yang tidak dikelola dengan baik dapat membawa kemunduran dalam suatu kegiatan usaha. Dalam rangka mengelola brand dengan baik, pemilik usaha harus memahami terlebih dahulu apa itu brand dan struktur dasar yang membentuk brand tersebut. Pengelolaan brand dapat melibatkan pihak lain yang berkompeten dalam penanganan brand, bila pemilik usaha merasa tidak mampu mengelola brand secara mandiri. Praktisi branddituntut untuk memahami brand secara mendalam sebelum menangani proyek-proyek yang berkaitan dengan pengembangan brand. Permasalahan yang muncul adalah banyaknya pemahaman 
mengenai brand dan ada praktisi yang belum mendapatkan pengenalan secara utuh mengenai brand itu sendiri.Sehingga ada kesenjangan makna brand yang dipahami oleh masing-masing praktisi brand.

Berdasarkan

Undang-Undang

Republik Indonesia Nomor 15 Tahun Tentang Merek, brand (merek)adalah unsur dalam suatu barang atau jasa yang memiliki daya pembeda. Daya pembeda ini berguna agar konsumen dapat membedakan barang dan jasa dari satu produsendengan produsen lainnya. Unsur yang dimaksud oleh undang-undang ini berupa gambar, nama, kata-kata, huruf-huruf, angkaangka, susunan warna atau kombinasi dari hal-hal tersebut yang memiliki daya pembeda.Definisi brand tidak berhenti dalam kalimat yang terdapat dalam undang-undang tersebut, namun berkembang seiring kemajuan zaman. Pendefinisian brand dalam undang-undang lebih kepada penegasan kepastian hukum terhadap hal-hal yang perlu dijaga oleh pemilik brand, sehingga memiliki kekuatan hukum saat terjadi permasalahan pada suatu waktu.

Unsur pembentuk brand yang dijelaskan oleh undang-undang masih bersifat konvensional, atau unsurunsur yang terbentuk atas kesepakatan secara umum.Perkembangan zaman dan persaingan bisnis menuntut setiap pemilik usaha untuk mengembangkan struktur brand agar semakin berdaya saing.Pengembangan brand tidak berhenti secara konvensional saja, namun patut untuk menyentuh hal-hal bersifat strategis. Unsur bersifat strategis akan berbeda-beda perlakuannya bagi setiap brand yang dikelola, sehingga akan menghasilkan daya pembeda di atas rata-rata dibandingkan bila menggunakan unsur-unsur bersifat konvensional saja.Charles Brymer (CEO dari Interbrand Schecter) mengatakan bahwa "kami mendefinisikan brand sebagai trademark, yang kepada konsumen merepresentasikan nilainilai dan atribut tertentu".

Perkembangan definisi brand sebagai unsur strategis,hendaknya diiringi dengan pemahaman mengenai struktur mendasar dari brand. Dengan demikian setiap unsur yang dibangun tidak melenceng fungsi dari bentuk dasarnya. Studi terhadap perkembangan brand, membawa pemahaman mengenai bagaimana fungsi dasar brand dan bagaimana brand dapat dikembangkan secara terarah.Sejarah perkembangan brand dari waktu ke waktu akan memberikan gambaran pola struktur, fungsi dan manfaat secara tradisional, sifat tradisional ini dilihat sebagai hal yang benar-benar mendasar dari masyarakat di masa lalu 


\section{METODE PENELITIAN}

Metode yang digunakan dalam penelitian ini adalah studi literatur.Penelitian jenis ini dilakukan dengan mencari data yang relevan, sesuai permasalahan yang diangkat.Data diperoleh dari sumbersumber ilmiah yang dapat dipertanggungjawabkan keabsahannya. Sumber-sumber ilmiah ini dapat berupa buku, jurnal, artikel dan situssitus di Internet.Pada penelitian ini digunakan segala data yang berkaitan dengan sejarah perkembangan brand, untuk memahami apa itu brand sebenarnya dan bagaimana suatu brand dikembangkan secara terarah tanpa menghilangkan fungsi dasarnya.

\section{PEMBAHASAN}

Davis (2005:18) menjelaskan bahwa kata 'brand' berasal dari bahasa Norwegia kuno 'brandr' yang berarti 'to burn' atau membakar. Dalam bentuk ini, brandmerupakan suatu perangkat (stempel yang dibakar) yang digunakan untuk menyatakan kepemilikan , asal-usul serta keterpautan.Berdasarkan temuan sejarah dari berbagai sumber, dapat dipaparkan mengenai sejarah perkembangan brand mulai dari tahun 2250SM hingga sekarang.

\section{Early Bronze IV (2250SM-2000SM)}

Kenoyer (1994 hal:75)menjelaskan mengenai temuan tertua, yang menjelaskan kemunculan brand berasal dari daerah Harappa di Lembah Indus. Terdapat segel persegi pada tembikar yang dibuat oleh pengrajin, sebelum dijual ke pedagang.Peran segel sebagai merek dagang tersebut dijadikan usaha untuk meningkatkan fungsi pemasaran, seperti untuk memudahkan penyortiran, penyimpanan dan tranporstasi saat dijual kembali.

\section{Lukisan pada Dinding Makam Mesir (2000SM)}

Davis (2005:18) menjelaskan tentanglukisan pada dinding makam Mesir, yang menggambarkan rekaman tentang penggunaan brand sebagai penanda kepemilikan atas ternak dan budak. Penggunaan brand pada ternak dan manusia tersebut memiliki maksud untuk menegaskan bahwa suatu entitas dimiliki dan berasal dari satu pemilik.

\section{The Midle Bronze Age (2000-1000SM)}

Reid (2008:11) menjelaskan bahwa dinasti Shang pada zamannya, menyelenggarakan pemerintahan melalui sistemzu atau kelompok kerabat. Kelompok-kelompok kecil ini digabungkan hingga menjadi kelompok yang lebih besar, yang dikoordinir oleh pemerintahan kota. Struktur pemerintahan ini menggambarkan bahwa semua perekonomian dan politik dikontrol oleh raja.Struktur pengelompokan ini dapat dikatakan sebagai awal 
terbentuknyabrand, karena dapat menggambarkan tentang asal-usul, kualitas dan kepemilikanatas wilayah serta isinyadari dinasti tersebut.

\section{The Late Bronze Age (1500-1000 SM)}

Setiap produk tembaga memiliki simbol status dan nilai ditentukan oleh asal usul bahan bakunya.Cyprus dikenal sebagai penghasil bahan baku tembaga yang baik, sehingga setiap produk tembaga yang dihasilkan memiliki simbol status dan nilai yang baik pula. Dalam hal ini Cyprus memiliki atribut yang tertanam dalam benak masyarakat zaman itu, sebagai penghasil bahan baku tembaga berkualitas terbaik (Reid. 2008).

\section{The Iron Age Revolution(1000-500 SM)}

Pada masa ini Melquart merupakan pemimpin perdagangan multinasional yang memperdagangkan barangbarang mewah.Melquart mencerminkan informasi kualitas utama merek (kualitas, asal) dengan memanfaatkan image dalam kombinasi yang kuat dengan tujuan menunjukkan kekuasaan atau status dan nilai (Reid. 2008).

\section{The Iron Age (825-336 SM)}

Revolusi pasar bebas di Yunani membawa budaya kewirausahaan yang tak tertandingi dalam masyarakat sebelumnya. Perubahan ini tercermin dalam praktek branding yang dibangun melaluiproto- brandtradisional,menggambarkan informasi mengenai asal dan kualitas. Salah satu penerapannya adalah penggunaan Aprodhite untuk penjualan sebagai simbolisme seks, untuk mengkonotasikan karakteristik kepribadian produsen (Reid. 2008)

\section{Era Branding Awal (Sebelum Tahun $1870 \mathrm{M}$ )}

Branding digunakan untuk mengidentifikasi nama pembuat produk. Hal ini dilihat dari penggunaan tanda pengenal pada porselin Tiongkok kuno.Masyarakat Yunani dan Romawi kuno juga menggunakan tanda untuk mengidentifikasi barang, hewan ternak dan lain-lain.Walau demikian, sebagian besar produsen masih membuat produk tanpa merek (Tjiptono 2005).

\section{Era Manufaktur (1870 - 1914 M)}

Kemajuan teknologi membawa pertumbuhan fungsi brand yang ditandai dengan adanya perubahan UU merek dagang di Amerika. Kekuatan dalam saluran distribusi berada di tangan pemanufaktur, yang menentukan apa yang akan diproduksi. Konsumen mulai menggunakan merek sebagai sinyal kualitas sewaktu memutuskan pilihan diantara produk dari berbagai produsen (Tjiptono 2005).

\section{Era Merek Nasional (1915 - 1929 M)}

Periode ini merupakan masa keemasan brand pemanufaktur, dimana 
mayoritas telah mapan secara regional maupun nasional. Pemasaran merek mulai ditangani oleh para maajer spesialis fungsional dan eksekutif biro periklanan. Merek-merek menstimulasi berkembang biaknya praktik imitasi dan pembajakan (Tjiptono 2005).

\section{Era Store Brand (1930 - 1949M)}

Store brands muncul dan berkembang sebagai alternatif yang lebih murah untuk merek pemanufaktur seiring dengan semakin sensitifnya konsumen terhadap harga akibat resesi dunia di dekade 1930 (The Great Depression).Procter\& Gamble memulai sistem manajemen merek pertama, dimana seorang manajer merek khusus ditugaskan dan bertanggungjawab atas kesuksesan finansial sebuah merek, hal ini belum banyak diikuti oleh perusahaan lainnya (Tjiptono. 2005).

\section{Era Manajer Merek (1950 - 1985 M)}

Seiring dengan membaiknya ekonomi pasca Perang Dunia II, permintaan akan merek pemanufaktur kembali bertumbuh. Hal ini diikuti dengan meningkatnya pendapatan personal, membanjirnya produk baru hingga semakin maraknya pertumbuhan iklan televisi. Adopsi sistem manajer merek meluas hampir di semua perusahaan di Amerika. Ini adalah asal mula business team, program manager, brand sales manager dan category manager.
Era Brand As A Concept 1985 -

\section{Sekarang}

Terjadi perubahan paradigma dari brand sebagai tambahan produk menjadi brand sebagai konsep.Merek mulai dicantumkan dalam neraca sejumlah perusahaan dan mulai dikenal kata ekuitas merek bagi pemasar. Lebih lanjut, sebuah brand yang sukses bahkan dapat menjadi aset perusahaan yang memiliki nilai nominal seharga bilyunan dolar! Status brand termahal di dunia saat ini dimiliki oleh Coca Cola. Dalam waktu 118 tahun sejak berdiri, saat ini nilai mereknya sudah bertumbuh mencapai angka US\$ 70 billion. Harga tersebut sangat luar biasa bila dibandingkan dengan nilai aset fisik perusahaan yang 'hanya' sepertiganya, yakni US\$ 24.5 billion (Rie.2004:18).

\section{PEMBAHASAN}

Berdasarkan data hasil penelitian studi literatur yang telah dipaparkan pada bagian hasil penelitian, dapat dipahami bahwa branddari waktu ke waktu mengalami perkembangan fungsi. Dalam mengembangkan brand di masa kini dan dimasa mendatang, pengelola perlu menjaga fungsi-fungsi yang sudah ada sehingga tidak kehilangan hal yang mendasar.Berikut fungsi mendasar berdasarkan uraian perjalanan sejarah tentang perkembangan brand dari masa ke masa: 
Brand untuk menunjukkan kepemilikan terhadap suatu entitas.

Brand menjadi suatu penanda yang dapat menunjukkan kepemilikan asal (produsen) atas barang dan jasa yang perdagangkan di pasar.Dengan demikian konsumen dapat mengidentifikasi siapa yang bertangung jawab terhadap barang dan jasa yang dibelinya.

\section{Brand memudahkan penyortiran, penyimpanan dan transportasi.}

Dalam kegiatan distribusi, tidak menutup kemungkinan bahwa suatu produk akan disimpan dan diangkut bersamaan dengan produk lain.Fungsi brand sebagai penanda untuk memudahkan proses distribusi yang terdiri dari penyortiran, penyimpanan dan transportasi.

Brand menunjukkan asal-usul dan persepsi kualitas.

Masyakarakat yang telah menggunakan produk berupa barang dan jasa dari suatu produsen akan merasakan 'pengalaman sebagai pengguna'. Pengalaman ini membentuk persepsi masyarakat terhadap kualitas produk yang digunakannya, bila pengalaman yang didapatkannya positif maka akan timbul persepsi kualitas yang positif, begitu pula sebaliknya. Masyarakat akan menganggap bahwa setiap produk yang dikeluarkan oleh suatu produsen akan dianggap sebagai produk yang berkualitas baik.

\section{Brand untuk membangun dan} menanamkan atribut status dan nilai. Selain keunggulan secara fisik, terdapat pertimbangan lain dimana konsumen menentukan pilihannya pada suatu produk. Keuntungan nonfisik ini dapat berupa atribut status dan nilai yang melekat pada brand yang terkait, status dan nilai ini menjadi salah satu keunggulan yang tidak berbentuk fisik yang sulit untuk dijiplak atau dibajak oleh produsen lain.

\section{Brand membangun personalistas} produk dan jasa.

Nilai yang terbangun dari suatu brandkesesuaian karakter produk dengan kepribadian konsumen.Brand yang dikelola dengan baik akan memperhatikan karakter produk yang disesuaikan dengan kepribadian konsumen. Kesamaan ini akan mendekatkan konsumen pada suatu brand yang terkait.

\section{Brandmengarahkan}

keputusan

\section{konsumen.}

Diantara banyaknya produk yang ada di pasaran, brandakan memberikan bahan pertimbanganbagi konsumen menggunakannya.Bahan pertimbangan ini diperoleh dari setiap fungsi brand yang sudah dijelaskan pada poin-poin sebelumnya. Bila tidak ada pertimbangan yang cukup 
meyakinkan, konsumen akan cenderung memilih brand lain dengan pertimbangan yang lebih baik.

\section{Brand Menjadi konsep dalam meluncurkan produk baru.}

Melalui nilai-nilai yang terkandung dalam suatu brand, produsen dapat meluncurkan produk secara konsisten untuk menjaga persepsi masyarakat terhadap brand tersebut.Brand dapat berperan sebagai konsep atau tema mendasar untuk semua aktifitas bisnis atau pemasaran.

\section{Brand membangun aset dan kesuksesan finansial.}

Brand yang berhasil meraih banyak konsumen akan menjadi aset bisnis berharga bagi perusahaan, karena memiliki kekuatan untuk mendatangkan konsumen baru dan mempertahankan pelanggan lama.Brand yang seperti ini akan memiliki kemapanan dan peluang untuk berkembang dari sisi finansial. Bisnis dengan aset yang baik akan bernilai tinggi untuk dijual atau ditawarkan kepada para investor.

\section{KESIMPULAN}

Dalam penelitian ini dapat disimpulkan bahwa fungsi brand memegang peranan dalam kegiatan bisnis dan pemasaran.Pola penggunaan brand berkembang dari ranah konvensional hingga akhirnya menjadi ranah strategis yang menjadikan suatu produk memiliki konsep yang kuat untuk bersaing dan berkembang mengatasi perkembangan zaman.

\section{DAFTAR PUSTAKA}

1. Wibowo, Tri. 2002. Teori warna untuk desainer. $\mathrm{T}$ desain!Hidup berkualitas tak sekedar kuantitas, (online), (www.triwibowo.com/teori-warna-untukdesainer-2, diakses 10 Juli 2013).

2. Davis, Melissa dan Baldwin, Jonathan. 2005. More Than a Name: An Introduction to Branding. Lausanne: An AVA Book.

3. Kenoyer, Jonathan Mark. 1994, "The Harappan State, Was it or Wasn't it?" in From Sumer to Meluhha: Contributions to the Archaeology of South and West Asia in Memory of George F. Dales, Jr., Jonathan Mark Kenoyer, ed. Madison. WI: Prehistory Press, 71-80.

4. Reid, Susan dan Moore, Karl.2008. The Birth of Brand: 4000 Years of Branding History. Muenchen: McGill Universty.

5. Republik Indonesia. 2001. Undang-Undang No.15 Tahun 2001 tentang Merek. Lembaran Negara RI Tahun 2001 No.4131. Sekretariat Negara. Jakarta

6. Ries, Al. 2004. The Origin of Brands: Discover The Natural Laws of Product Innovation and Business Survival. New York: Harper Collins Publisher.

7. Rustan, Surianto. 2009. Mendesain Logo. Jakarta: PT Gramedia Pustaka Utama.

8. Tjiptono, Fandy. 2005. BRAND Management \& Strategy.Yogyakarta: Andi. 